GieRTyCh, M. (1987): Seed orchards in crisis. Forest. Ecol. Manag. 19: 1-7.

GIL, L. (1999): La transformación histórica del paisaje: la permanencia y la extinción local del pino piñonero, pp. 151-185 in Los montes y su historia - una perspectiva política, económica y social, edited by MARín, F., DOMINGO, J., CAlZAdo, A., Universidad de Huelva, Huelva.

Gordo, J. (2004): Selección de grandes productores de fruto de Pinus pinea en la Meseta Norte. Ph. D. Thesis, Universidad Politécnica de Madrid, Madrid.

KJÆR, E. D. and H. WELLENDORF (1997): Variation in Flowering and Reproductive Success in a Danish Picea abies (Karst.) Seed Orchard. Forest Genet. 4(4): 181-188.

LANNER, R. M. (1981): The Piñon Pine - A Natural and Cultural History. University of Nevada Press, Reno, USA.

Magini, E. and R. Giannini (1971): Prime osservazioni sulla produzione di strobili e semi di un parco di cloni di pino domestico (Pinus pinea L.). L'Italia Forestale e Montana XXVI(2): 63-78.

MATZIRIS, D. (1993): Variation in cone production in a clonal seed orchard of black pine. Silvae Genet 42(2-3): 136-141.

Meredith, M. P. and S. V. Stehman (1991): Repeated measures experiments in forestry: focus on analysis of response curves. Can. J. For. Res. 21: 957-965.

Mutke, S., J. Gordo and L. GIL (2000): The Stone Pine (Pinus pinea L.) Breeding Programme in Castile-Leon (Central Spain). FAO Nucis-Newslett. 9: 50-55.

Mutke, S., J. Gordo, J. Climent and L. GiL (2003a): Shoot Growth and Phenology Modelling of Grafted Stone Pine (Pinus pinea L.) in Inner Spain. Ann. For. Sci. 60(6): 527-537.

Mutke, S., B. SadA, S. Iglesias and L. Gil (2003b): Evaluación de la producción individual de piña en un banco clonal de pino piñonero (Pinus pinea L.) en Madrid. Invest. Agr.: Sist. y Recur. For. 12(1): 149-157.
Mutke, S., R. Sievänen, E. NikinmaA, J. Perttunen and L. GIL (2005): Crown architecture of grafted Stone pine (Pinus pinea L.): shoot growth and bud differentiation. Trees 19(1): 15-25.

NikkANEN, T. and P. Velling (1987): Correlations Between Flowering and Some Vegetative Characteristics of Grafts of Pinus sylvestris L. For. Ecol. Manag. 19: $35-40$.

Nikkanen, T. and S. Ruotsalainen (2000): Variation in flower abundance and its impact on the genetic diversity of the seed crop in a Norway spruce seed orchard. Silva Fenn. 34(3): 205-222.

Prada, M. A., J. Gordo, J. De Miguel, S. Mutke, G. Catalán, S. Iglesias and L. Gil (1997): Las regiones de procedencia de Pinus pinea L. en España. MAPA, Madrid.

Smith, W. H. and R. G. Stanley (1969): Cone Distribution in Crowns of Slash Pine (P. elliottii Engelm.) in Relation to Stem, Crown and Wood Increment. Silvae Genet. 18: 86-91.

Smith, R. F. (1987): The effects of fertilization on flowering of various-sized Black spruce (Picea mariana) trees. For. Ecol. Manag. 19: 189.

SNEDECOR, G. W. and W. G. CochraN (1967): Statistical Methods. Iowa State Univ. Press, Ames.

Sutton, A., R. J. Staniforth and J. TARDif (2002): Reproductive ecology and allometry of red pine (Pinus resinosa) at the northwestern limit of its distribution range in Manitoba, Canada. Can. J. Bot. 80: 482-493.

Thirgood, J.V. (1981): Man and the Mediterranean Forest. A history of resource depletion. Academic Press, London.

WolfF, R. L. and C. C. BAYARD (1995): Fatty acid composition of some pine seed oils. J. Am. Oil Chem. Soc. 72: 1043-1046.

\title{
Conservation Approaches For Autochthonous Woody Plants in Flanders
}

\author{
By K. VANDER MijnsbrugGe ${ }^{1,2)}$, K. CoX ${ }^{1)}$ and J. VAN SLYCKeN ${ }^{1)}$
}

(Received 19 ${ }^{\text {th }}$ April 2005)

\begin{abstract}
Autochthonous genetic resources of woody plants have become seriously endangered in Flanders because of the particularly low and fragmented forest cover, centuries of intensive forest use in this highly populated area and the wide-spread usage of non-autochthonous planting stock in reforestation and landscape plantings. Intraspe-

1) Institute for Forestry and Game Management, Gaverstraat 4, B-9500 Geraardsbergen, Belgium.

2) Corresponding author: kristine.vandermijnsbrugge@inbo.be, Tel: 3254437146 , Fax: 3254436160 .
\end{abstract}

cific hybridisation between remnant autochthonous populations and foreign genotypes, which can show inadequate adaptation, may influence the autochthonous genetic constitution and fitness in the long term. As several European countries face similar problems, the objective of this paper is to outline the conservation measures that are taken in Flanders. The central aim is to maintain and create the necessary conditions for natural and flexible evolution of the genetic diversity of autochthonous trees and shrubs. An inventory survey to locate remaining autochthonous populations was started in 1997 and will be completed in 2006. Relict populations are preserved in clonal banks. Central issues are 
the production of autochthonous planting stock through in situ seed collection, the approval of seed sources and stands and the creation of seed orchards. Conservation actions are discussed.

Key words: in situ conservation, ex situ conservation, autochthonous woody plants, seed orchards, forest reproductive material, clonal banks, regions of provenance, seed collection, natural populations, inventory.

\section{Introduction}

\subsection{Autochthonous trees and shrubs}

After the last ice age, woody plants in Europe migrated north and west from glacial refugia along the Mediterranean Sea and in the East. Populations adapted to local and regional conditions of climate, hydrology and soil. As long-living organisms, woody plants developed in the course of their evolution a high degree of genetic diversity (e.g. HAMRICK, 1992; GREGORIUS and Kleinschmit, 1999; Newton et al., 1999). Current genetic differentiation among populations can originate from adaptation to local ecological conditions, adaptation to previous growth conditions, accidental events during migration, influx of genes from neighbouring populations, genetic drift, spontaneous mutations and directed selection by humans (e.g. JOLY and FrASCARIA-LACOSTE, 2001). The term autochthony indicates the continuous existence (i.e. genealogical continuity) of woody plants at a specific site since the arrival of the species after post-glacial remigration. (KLEINSCHMIT et al., 2004). In comparison, the term native denotes that the growing site is a part of the natural geographic range of the species, and does not automatically imply local adaptation. The origin of reproductive material is the original growing site of parental plants, from which seeds or cuttings are collected. The seed source only refers to the area where seeds were obtained.

\subsection{An alarming situation}

The forest cover in Flanders is one of the lowest in Europe (10.8\%). Only about $5 \%$ of this cover holds autochthonous populations (VANDER MiJnsBRUGGE et al., $2003 \mathrm{~b})$. Many causes can be indicated for this. Best known is the deforestation and intensive forest use that started during the early Middle Ages (TACK et al., 1993), when the Lower Netherlands were the most densely populated region north of the Alps. During the last century, species selected for wood production were most often used for reforestation in Flanders. Changes in land use (large-scale expansion in agriculture, unstructured urbanisation,...) have further diminished and fragmented the forest cover. A less well known threat is the use of foreign provenances of forest reproductive material that are currently marketed in Flanders (VANDER MiJnsBRUGGe, 2003). After decades of research on economically valuable tree species, it became apparent that the origin or provenance of planting stock considerably influences the chances of success of a plantation (e.g. Picea abies, DANusevicius and Persson, 1998; Quercus robur and $Q$. petraea, SvOLBA and KLEINSCHMIT, 2000; Pseudotsuga menziesii, PRAT and BurCzYK, 1998). Due to a lack of approved seed stands and orchards in Flanders, forest tree nurseries need to import seeds from elsewhere. The origin of economically less important woody species is often not properly considered (VANDER MiJnsBRUGGe, 2003). Because of lower production costs at source, seed lots are imported from Southern and Eastern Europe. The resulting planting stock may be less well adapted to the regional growing conditions (e.g. Jones et al., 2001). Especially in Flanders, largescale planting of non-autochthonous provenances of native woody species can be a threat for relict autochthonous populations. It can cause changes in the genetic diversity as the plantations spread foreign genes through cross-pollination. The large quantity of nonautochthonous planting stock utilised in Flanders creates potential risks of founder effects, genetic swamping (i.e. the rapid increase in frequency of an introduced genotype that might lead to replacement of local genotypes due to numerical and/or fitness advantage) and outbreeding depression (HUFFORD and MAZER, 2003). It can also disturb evolutionary processes (SACKVILLE HAMilton, 2001).

\subsection{Reasons for conservation}

The Rio Convention (CBD 1992) states that biodiversity does not only encompass the diversity of species, communities and ecosystems. Lower in the taxonomic hierarchy, genetic diversity is a necessary means of survival in dynamic ecological equilibria. Long-lived tree and shrub species need to maintain their genetic diversity in order to ensure that their progeny can remain well adapted to complex heterogeneous environments (BEHM et al., 1997, KLEINSCHMiT et al., 2004).

It is a buffer against biotic and abiotic stresses. Populations with low adaptability will face extinction in the long term (e.g. Hedrick 2001). In addition to the Rio Convention, which covers all living organisms, several resolutions of the Ministerial Conferences on the Protection of Forests in Europe explicitly emphasise the urgency of preservation of local autochthonous genetic resources (MCPFE 2005). As trees are long-lived organisms and silviculture implies long rotation ages, genetic diversity is the most significant reason to conserve the autochthonous populations of woody plants. From a panEuropean perspective, the European Forest Genetic Resources Programme (EUFORGEN) was constituted as a collaborative network among European countries to put several resolutions of the MCPFE into practice. These include the Strasbourg Resolution S2 on the conservation of forest genetic resources and the Vienna Resolution 4 on conserving and enhancing forest biological diversity in Europe (EUFORGEN 2005). Measures are being taken on a national scale (e.g. Germany: BEHM et al., 1997; England: EnNos et al., 2000; Denmark: GRAUDAL et al., 1995; Great Britain: WILsON et al., 2004; HeRBERT et al., 1999; France: TEISSIER DU CROS, 2001; Scotland: WiLson et al., 1999, etc).

\subsection{Aims and scope of the programme}

The central aim of the programme described in this paper is to establish and maintain the indispensable prerequisites for securing evolutionary adaptability of autochthonous trees and shrubs in Flanders. The Forestry Administration of the Flemish Community 
together with the Institute of Forestry and Game Management protect the genetic variation of local populations through dynamic in situ and ex situ conservation strategies (VANDER MiJnsbrugGe, 2003; VANDER MiJnsBRUGGE et al., 2003a, 2003b). Because autochthonous relict populations are scattered and sometimes extremely rare, a systematic inventory of autochthonous woody plants is a necessity in order to implement conservation actions. An inventory survey was commenced in 1997 and will be completed in 2006 (see 2.2). For rare and endangered species, gene stock from remnant individuals and highly depleted populations are collected in clonal banks as an ex situ conservation measure (see 2.5). The ultimate goal is to make regionally autochthonous planting stock commercially available, to counteract the large scale and widespread usage of non-autochthonous planting stock both in forestry and landscape plantings. In situ seed collection, the official approval of seed sources and stands, and the creation of seed orchards are organised to this end. (see 2.6 and 2.7). The programme is supported by informing all parties involved, and by applied scientific research (see 2.8).

\section{Conservation approaches}

\subsection{New legislation}

The European Directive 1999/105/EC (ANONYMous, 2000) necessitated the revision of national legislation on the marketing of forest reproductive material. This resulted in the Flemish Decree of 3 October 2003 on the procedure for approval of basic material and marketing of forest reproductive material (ANONYMOUs, 2003a). The Decree regulates several aspects that are important for the conservation approach. (i) According to this Decree, the Institute for Forestry and Game Management is responsible for the delineation of regions of provenance (see 2.3). These areas are characterised by uniform ecological growing conditions, where stands and seed sources display similar phenotypic and genetic characteristics. (ii) The new categories 'source identified' and 'qualified' for forest reproductive material are included, in addition to the existing categories 'selected' and 'tested'. As no evaluation of economically significant timber form traits is required for the category 'source identified', it is applicable for autochthonous seed sources and stands (see 2.6). (iii) Former legislation placed more emphasis on timber production potential and among the native tree species of Flanders only Quercus spp., Populus spp. and Fagus sylvatica were subject to certification of their forest reproductive material. In the new Decree nearly all native forest tree species become subject to certification. In addition, a facultative list of shrub species and secondary tree species provides the opportunity for certification of autochthonous provenances. (iv) All approved seed sources and stands are summarized in a national list.

In addition to the Decree on the marketing of forest reproductive material, two recent Decrees deal with subsidies for the use of 'recommended' provenances in (re)forestation initiatives (ANONYMOUS, 2003b, 2003c). The list of recommended provenances contains provenances of native tree and shrub species including seed stands and orchards from Flanders, the Walloon region and neighbouring countries. These are selected on the basis of vitality, adaptability and silvicultural quality. All officially approved autochthonous seed sources and stands in Flanders are added to the list. The use of autochthonous trees and shrubs is encouraged by the offer of grants to plant recommended provenances.

\subsection{Inventory: relicts of genetic resources}

The relict populations of autochthonous woody plants have been surveyed since 1997 by specialised botanists, on the authority of the Flemish Community (MAEs and RÖVEKAMP, 1998; RöveKAMP and MAes, 1999; MAEs and RÖVEKAMP, 2000; RÖVEKAMP and MAES, 2000; RÖVEKAMP et al., 2000; Opstaele, 2001; MAEs et al., 2003). The inventory focuses on all native phanerophytes and includes botanical varieties, subspecies and hybrids. The methods of MAEs et al. (1991) and MAEs (1993) to evaluate the autochthony of a tree or shrub have been followed. Initially, extant woodlands (e.g. forests, wooded banks and thickets) are selected if they are indicated as forest on the Ferraris map of 1779 or on other historical maps (DE KEERSMAEKER et al., 2001). Information on flora, soil conditions and geomorphologic data are used to further refine the selection of potentially relevant sites. In the field, trees and shrubs are evaluated according to a set of criteria: (a) the tree or shrub is of a wild variety, not a cultivar. For example, pubescence on the leaves of wild apple trees (Malus sylvestris) indicates the influence of cultivated apple (WAGNER, 1999). (b) The tree or shrub is old. Large coppice stools can attain particularly old age, amounting to several hundred years (e.g. for lime, PigotT, 1989). (c) No evidence of plantation (e.g. trees in lines) can be seen. (d) The site is located within the natural geographic range of the species and the growing conditions correspond with the ecological requirements of the species. (e) The tree or shrub is present on similar sites in the neighbourhood. (f) Several plants present in the tree, shrub or herb layer are indicators of ancient undisturbed woodland. These summarised criteria are evaluated in relation to each other. E.g. old hedges were possibly planted with local material and can therefore be regarded as autochthonous, although the individual plants are clearly planted in one line.

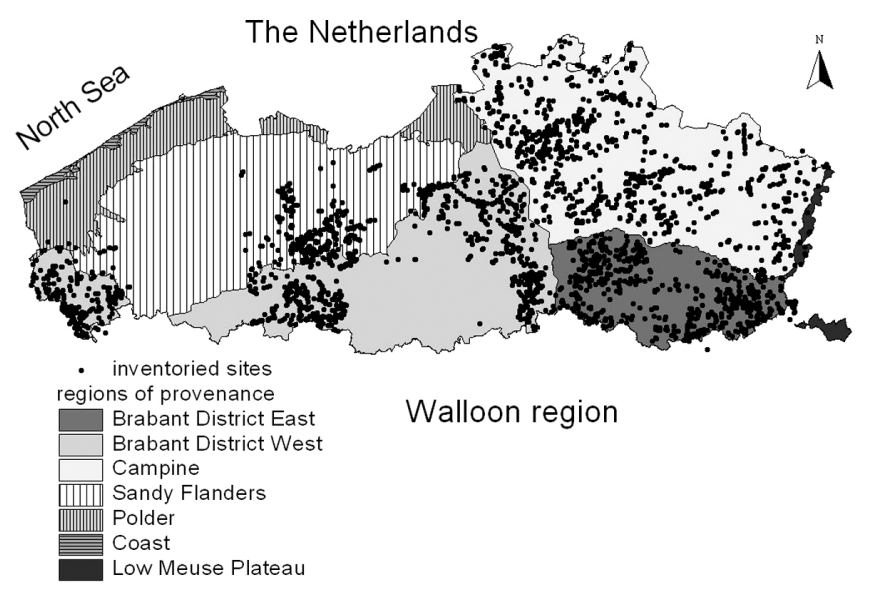

Figure 1. - Surveyed autochthonous sites. 
Table 1. - Basic material for autochthonous planting stock. Indicated are species name, presence of autochthonous genetic resources in Flanders, type of basic material for the seed orchards, number of regions of provenance for which orchards are established, type of certification, realisations in the field (2005) and number of approved seed sources and stands.

\begin{tabular}{|c|c|c|c|c|c|c|}
\hline Scientific name (a) & $\begin{array}{l}\text { Pr \% } \\
\text { (b) }\end{array}$ & $\mathrm{Bm}(\mathrm{c})$ & Pv (d) & $\mathrm{Ce}(\mathrm{e})$ & $\operatorname{Re}(f)$ & Ap (g) \\
\hline Tilia platyphyllos & 0,38 & $\mathrm{cu}, \mathrm{gr}$ & 1 & $\mathrm{O}$ & $62 *, 0.14 *, F 1$ & \\
\hline Ulmus laevis & 0,57 & $\mathrm{cu}, \mathrm{gr}$ & 1 & $\mathrm{~F}$ & $\mathrm{~N}, \mathrm{Fl}$ & \\
\hline Malus sylvestris & 0,61 & $\mathrm{gr}$ & 1 & $\mathrm{~F}$ & $108^{*}, 0.27^{*}, \mathrm{~F} 1$ & \\
\hline Populus tremula & 0,64 & gr & 1 & $\mathrm{O}$ & $\mathrm{N}, \mathrm{Fl}$ & \\
\hline Tilia cordata & 1,10 & $\mathrm{cu}, \mathrm{gr}$ & 1 & $\mathrm{O}$ & $235^{*}, 1.54^{*}, \mathrm{Fl}$ & \\
\hline Ilex aquifolium & 1,17 & $\mathrm{cu}$ & 2 & $\mathrm{~F}$ & & \\
\hline Salix fragilis* & 1,25 & $\mathrm{cu}$ & 2 & $\mathrm{~F}$ & & \\
\hline Ulmus glabra & 1,63 & $\mathrm{cu}$ & 1 & $\mathrm{~F}$ & & \\
\hline Betula pendula & 1,74 & $\mathrm{cu}$ & 4 & $\mathrm{O}$ & & \\
\hline Quercus petraea & 2,08 & $\mathrm{gr}$ & 1 & $\mathrm{O}$ & N, KEM & 3 \\
\hline Mespilus germanica & 2,65 & $\mathrm{cu}$ & 3 & $\mathrm{~F}$ & $\begin{array}{l}45^{*}, 0.04^{*}, \mathrm{BDW}-\mathrm{N}, \\
\mathrm{VZA}\end{array}$ & \\
\hline Salix alba* & 3,03 & $\mathrm{cu}$ & 2 & $\mathrm{~F}$ & $\begin{array}{l}\text { N, BDW - N, BDO - } \\
\text { N, VZA }\end{array}$ & \\
\hline Salix aurita & 3,67 & $\mathrm{cu}$ & 2 & $\mathrm{~F}$ & & \\
\hline Betula pubescens & 3,94 & $\mathrm{cu}$ & 4 & $\mathrm{O}$ & & \\
\hline Acer campestre & 5,49 & $\mathrm{cu}$ & 2 & $\mathrm{~F}$ & $153^{*}, 1.21^{*}, \mathrm{BDW}$ & \\
\hline Prunus padus & 5,57 & $\mathrm{cu}$ & 3 & $\mathrm{~F}$ & $\begin{array}{l}445^{*}, 0.34 *, \mathrm{BDW}-\mathrm{N} \\
\text { BDO }\end{array}$ & \\
\hline Euonymus europaeus & 6,25 & $\mathrm{cu}$ & 2 & $\mathrm{~F}$ & $223^{*}, 0.16^{*}, \mathrm{BDW}$ & \\
\hline Rosa arvensis & 6,82 & $\mathrm{cu}$ & 1 & $\mathrm{~F}$ & $333^{*}, 0.27 *, \mathrm{BDW}$ & \\
\hline Quercus robur & 8,75 & gr & 2 & $\mathrm{O}$ & N, KEM - N, VZA & 3 \\
\hline Crataegus laevigata & 9,20 & $\mathrm{gr}$ & 2 & $\mathrm{~F}$ & & \\
\hline Prunus avium & 13,40 & $\mathrm{gr}$ & 1 & $\mathrm{O}$ & $\mathrm{N}, \mathrm{Fl}$ & \\
\hline Carpinus betulus & 14,16 & $\mathrm{cu}, \mathrm{gr}$ & 1 & $\mathrm{O}$ & $\mathrm{N}, \mathrm{Fl}$ & \\
\hline Ulmus minor & 14,54 & $\mathrm{cu}$ & 3 & $\mathrm{~F}$ & & \\
\hline Prunus spinosa & 14,96 & $\mathrm{cu}$ & 2 & $\mathrm{~F}$ & $182 *, 0.16^{*}, \mathrm{BDW}$ & 3 \\
\hline Alnus glutinosa & 15,83 & gr & 3 & $\mathrm{O}$ & & 7 \\
\hline Sorbus aucuparia & 15,83 & $\mathrm{cu}$ & 4 & $\mathrm{~F}$ & $\begin{array}{l}276,0.95, \mathrm{BDW}-\mathrm{N}, \\
\text { KEM }\end{array}$ & 2 \\
\hline Salix cinerea & 17,40 & $\mathrm{cu}$ & 4 & $\mathrm{~F}$ & & \\
\hline Fraxinus excelsior & 18,02 & $\mathrm{gr}$ & 4 & $\mathrm{O}$ & $\begin{array}{l}\text { N, BDO - N, BDW - } \\
\text { N, VZA - N, KEM }\end{array}$ & \\
\hline Cornus sanguinea & 18,36 & $\mathrm{cu}$ & 2 & $\mathrm{~F}$ & $508,0.42, \mathrm{BDW}$ & \\
\hline Salix caprea & 22,60 & $\mathrm{gr} / \mathrm{cu}$ & 4 & $\mathrm{~F}$ & & \\
\hline Rhamnus frangula & 22,61 & $\mathrm{cu}$ & 4 & $\mathrm{~F}$ & N, KEM & 2 \\
\hline Crataegus monogyna & 24,27 & se & 4 & $\mathrm{~F}$ & $\begin{array}{l}127^{*}, 0.15^{*}, \mathrm{BDW}-\mathrm{N}, \\
\text { BDO - N, VZA - N, } \\
\text { KEM }\end{array}$ & 4 \\
\hline Viburnum opulus & 26,35 & $\mathrm{cu}$ & 4 & $\mathrm{~F}$ & $\begin{array}{l}318^{*}, 0.28 *, \mathrm{BDW}-\mathrm{N}, \\
\mathrm{VZA}\end{array}$ & \\
\hline Corylus avellana & 28,21 & $\mathrm{cu}, \mathrm{gr}$ & 4 & $\mathrm{~F}$ & $\begin{array}{l}42^{*}, 0.03 * \text {, BDDW - } \\
\text { N, KEM - N, VZA }\end{array}$ & 2 \\
\hline Rosa canina & 30,75 & $\mathrm{cu}$ & 4 & $\mathrm{~F}$ & N, BDW - N, VZA & \\
\hline
\end{tabular}

(a) *: derived forest reproductive material are cuttings in stead of seedlings.

(b) Pr \%: percentage of presence indicates the number of sites where the species is present, in comparison to the total number of surveyed sites in the inventory for autochthonous genetic resources.

(c) Bm: basic material for seed orchards: cu, cutting; gr, graft; se, seedling.

(d) $\mathrm{Pv}$ : number of regions of provenance for which seed orchards are established.

(e) Ce: obligatory, O, or facultative, F, certification of the planting stock according to the Flemish Decree on marketing of forest reproductive material (ANONYMOUs, 2003a).

(f) Re: realisations in the field (July 2005). Indicated are the number of plants planted, the surface (ha) and the region of provenance of the seed orchard. *, the seed orchard is not yet finalised, plants will be added. N, plants grown in nursery but not yet planted in the field. Fl, Flanders; BDW, Brabant District West; BDO, Brabant District East; KEM, Campine; VZA, Sandy Flanders.

(g) Number of approved autochthonous seed sources and stands, January 2005. 
Surveyed autochthonous sites are shown in Figure 1. They have an average size of 1.8 ha (VANDER MiJnsBRUGGE et al., 2003b). By 2007 the whole of Flanders will have been surveyed. So far the results of the inventory are concerning (VANDER MiJNSBRUGGe et al., 2003b). Only about $5 \%$ of the total forest cover in Flanders contains remnant autochthonous populations. About $40 \%$ of the surveyed sites are located within forests. The remainder comprise hedgerows, thickets and small landscape elements, mostly forming relict parts of large historical forests that have disappeared in the course of time. Tables 1 and 2 give an overview of the species that are subject to conservation.

Autochthonous populations of several silviculturally important tree species have become rare. Most striking is the case of native oak in Flanders. Although oak forests are very common, autochthonous Quercus robur and $Q$. petraea are relatively rare (present in $8.75 \%$ and $2.08 \%$ of surveyed sites respectively, Table 1 ). In the past centuries seed and planting stock of oaks have been translocated over long distances in Europe, resulting in present-day oak stands being of untraceable provenance. In contrast to other regions and neighbouring countries, local forest tree nurseries in Flanders are cited as growing several tree species in many sources from the $18^{\text {th }}$ century onward. Although seed may have been collected locally, translocations did occur (TACK et al., 1993). Only large oak coppice stools, dating back at least 500 years, display strong evidence for autochthony (VAnder MijnsbrugGe et al., 2003a). Chloroplast haplotype analysis of several autochthonous stands of $Q$. robur and $Q$. petraea in Flanders supported the autochthonous evaluation and localised the stands in the European re-migration routes since the last ice age

Table 2. - Autochthonous clonal banks. Indicated are species name, presence of autochthonous genetic resources in Flanders, type of basic material for the clonal banks, type of certification and realisations in the field (2005).

\begin{tabular}{|c|c|c|c|c|}
\hline Scientific name (a) & $\operatorname{Pr} \%(b)$ & $\mathrm{Bm}(\mathrm{c})$ & $\mathrm{Ce}(\mathrm{d})$ & $\operatorname{Re}(\mathrm{e})$ \\
\hline Berberis vulgaris* & 0,04 & - & $\mathrm{N}$ & \\
\hline Daphne mezereum* & 0,04 & - & $\mathrm{N}$ & \\
\hline Pyrus pyraster* & 0,04 & gr & $\mathrm{N}$ & \\
\hline Rosa stylosa & 0,04 & $\mathrm{cu}$ & $\mathrm{N}$ & N, BDW - N, KUS \\
\hline Andromeda polifolia & 0,08 & - & $\mathrm{N}$ & \\
\hline Sambucus racemosa & 0,08 & - & $\mathrm{N}$ & \\
\hline Vaccinium vitis-idaea & 0,08 & - & $\mathrm{N}$ & \\
\hline Oxycoccus palustris & 0,11 & - & $\mathrm{N}$ & \\
\hline Salix triandra & 0,11 & $\mathrm{cu}$ & $\mathrm{F}$ & \\
\hline Rosa micrantha & 0,15 & $\mathrm{cu}$ & $\mathrm{N}$ & $\mathrm{N}, \mathrm{BDO}$ \\
\hline Rosa rubiginosa & 0,19 & $\mathrm{cu}$ & $\mathrm{F}$ & N, BDO - N, KUS \\
\hline Salix purpurea & 0,19 & $\mathrm{cu}$ & $\mathrm{F}$ & \\
\hline Genista pilosa & 0,23 & - & $\mathrm{N}$ & \\
\hline Erica cinerea & 0,27 & - & $\mathrm{N}$ & \\
\hline Genista anglica & 0,30 & - & $\mathrm{N}$ & \\
\hline Lonicera xylosteum & 0,30 & - & $\mathrm{N}$ & \\
\hline Fagus sylvatica & 0,45 & $\mathrm{gr}$ & $\mathrm{O}$ & \\
\hline Juniperus communis & 0,49 & $\mathrm{cu}$ & $\mathrm{F}$ & \\
\hline Rosa agrestis & 0,49 & $\mathrm{cu}$ & $\mathrm{N}$ & $\mathrm{N}, \mathrm{BDO}$ \\
\hline Ligustrum vulgare & 0,57 & $\mathrm{cu}$ & $\mathrm{F}$ & \\
\hline Populus nigra & 0,57 & $\mathrm{cu}$ & $\mathrm{O}$ & $\mathrm{N}, \mathrm{Fl}$ \\
\hline Ulex europaeus & 0,57 & $\mathrm{cu}$ & $\mathrm{N}$ & \\
\hline Salix repens & 0,87 & $\mathrm{cu}$ & $\mathrm{F}$ & \\
\hline Rhamnus cathartica & 1,06 & $\mathrm{gr}$ & $\mathrm{N}$ & $\mathrm{N}, \mathrm{Fl}$ \\
\hline Myrica gale & 1,44 & - & $\mathrm{F}$ & \\
\hline Rosa pseudoscabriuscula & 3,03 & $\mathrm{cu}$ & $\mathrm{N}$ & $\begin{array}{l}\text { N, BDO - N, BDW - N, } \\
\text { KUS }\end{array}$ \\
\hline Rosa tomentella & 3,86 & $\mathrm{cu}$ & $\mathrm{N}$ & $\begin{array}{l}\text { N, BDO - N, BDW - N, } \\
\text { KUS }\end{array}$ \\
\hline
\end{tabular}

(a) *: the autochthonous character of the species in Flanders is not clear.

(b) $\operatorname{Pr} \%$ : percentage of presence indicates the number of sites where the species is present in comparison to the total number of surveyed sites in the inventory for autochthonous genetic resources.

(c) Bm: basic material for clonal banks: cu, cutting; gr, graft; se, seedling, - , not yet known.

(d) Ce: obligatory, $\mathrm{O}$, or facultative, $\mathrm{F}$, certification of the planting stock according to the Flemish Decree on marketing of forest reproductive material (ANONYMOUs, 2003a). N, species not mentioned in the Decree.

(e) Re: realisations (July 2005). N, plants grown in nursery, not yet planted in the field. Fl, Flanders; BDW, Brabant District West; BDO, Brabant District East; KEM, Campine; VZA, Sandy Flanders; KUS, coast. 
(COART, 2003; VANDER MiJnsbrugGe et al., 2003a). Also, similar analysis in an old remnant of a coppice with standards stand in Meerdaal Forest, the largest oak forest in Flanders, showed evidence of past translocation of forest reproductive material of oak. Among the standard oaks, dating from the $19^{\text {th }}$ century, both the expected Spanish chloroplast type and the non-autochthonous Balkan type were found (COART, 2003).

In less populated regions, the species composition of remnants of the old silvicultural coppice and coppice with standard systems may reflect the natural species composition. In Flanders, truly old stools are rare within relict coppice stands, indicating the intensity of historical human impacts. When the production of the stools diminished they were replaced with planting stock of which the provenance is now difficult to trace (TACK et al., 1993).

The history of Fagus sylvatica is very similar to oak as translocation of seed and planting stock may have been extensive. The largest forest in Flanders, Zoniën Forest, was largely planted in the period 1788-1794 under the authority of a Swiss forester Joachim Zinner (VAN DER BEN, 1997). The origin of the planting stock is unknown. Autochthonous relicts of F. sylvatica (present in $0.45 \%$ of surveyed sites, Table 2) are more restricted in comparison to those of native oak, possibly because beech does not persist under the coppice practice in Flanders. Only a few old coppice stools have been located.

Other examples are Tilia cordata and Tilia platyphyllos (present in 1.1 and $0.38 \%$ of the surveyed sites respectively, Table 1). Autochthonous populations have become rare, probably because for centuries Flemish forest users may have promoted other, at the time more useful, species. In the less populated northwestern region of France, more remnant old coppice stools of lime tree are present (TACK et al., 1993).

\subsection{Regions of provenance.}

Ideally, regions of provenance are defined according to ecological growing conditions, genetic variability between the natural populations of the tree and shrub species and information on adaptation and adaptability, which can be deduced in part from provenance trials (KLEINSCHMit et al., 2004). For most species in Flanders there is no information on the latter two subjects. Therefore, an initial small-scale provenance delineation is based on ecological conditions (climate, hydrology, soil) and the natural distribution patterns of the tree and shrub species as revealed by the inventory (VANDER MiJnsbrugGe et al., 2004, Fig. 1).

Based on climate, Flanders is subdivided into an Atlantic and Subatlantic area. The Atlantic area comprises a sandy soil region (Sandy Flanders in Fig. 1) and one with sand loam to loam soils (Brabant District West). Similarly, the Subatlantic region consists of a poor sandy soil region (Campine) and one with richer loamy soils (Brabant District East). Apart from these, small areas are considered as distinct sub regions of the regions of provenance because of the different ecological conditions: the coastal area (Coast) and the polders (Polder). The appropriate borderlines follow wherever possible (phyto)geographic, hydrologic or other non- administrative boundaries. Two smaller areas in the eastern part of Flanders are part of a larger region of provenance 'Low Meuse Plateau' which is mainly situated in the Walloon region. Both Brabant Districts West and East also continue in the Walloon region. If available, knowledge on the genetic constitution of populations can necessitate the adjustment of the delineation on a species-specific basis. This is the case for e.g. Quercus petraea and $Q$. robur (VANDER MiJNSBRUGGE et al., 2003a). For pragmatic reasons, the delineation of regions of provenance for rare and dispersed species is on a larger scale. The reduced populations for these species are too small in number and extent to allow appropriate seed collection on a small geographic scale, because the risk of diminished genetic variability is too great. For Ulmus laevis, Populus nigra, Tilia cordata and T. platyphyllos the whole of Flanders is considered as one region of provenance. In these cases also, research on genetic variability may result in a revised delineation.

\subsection{In situ conservation and Flemish policies}

Several policy instruments in Flanders protect autochthonous genetic resources. The Forestry Action Plan and the Management Concepts of the Forestry Administration (Forest and Green Areas Division 2003; Forest and Green Areas Division 2001) indicate that autochthonous relict populations in Flanders have to be inventoried and in situ and ex situ conservation measures have to be defined. When the populations are not too small and they can regenerate naturally, conservation action can be focussed on the preservation of their habitats. For many species in Flanders these two conditions are not satisfied. In addition, private ownership is another possible obstacle to in situ conservation. The private landowners are a highly diverse group. Many may not apply the appropriate treatment to the plant populations because of a lack of knowledge, a lack of interest and the financial cost that comes with proper management (Cox et al., 2005). In the south-western corner of Brabant District West (Fig. 1) $80 \%$ of the surveyed autochthonous sites are on private property (VANDER MiJNSBRUGGE et al., 2003b), indicating their vulnerable position. Due to the limited and fragmented forest cover and the restricted autochthonous populations, a strategy to preserve genetic resources through conservation of a number of stands under controlled silvicultural and administrative measures is not applicable in Flanders, as it is in Germany (BEHM et al., 1997) or France (TEISSIER DU CROS, 2001). Therefore, conservation action focuses on the creation of clonal banks of rare species and on the production of autochthonous forest reproductive material.

\subsection{Clonal banks of rare species}

Ex situ conservation by collecting plants in clonal banks is mandatory for locally or regionally endangered autochthonous populations, for which the size has become too small, the risk of disappearance is too high and/or a serious threat is imposed by a disease (e.g. Populus nigra, VANDEN BROECK, 2004; VANDER MiJnsbrugGe et al., 2003b). The loss of individuals has a higher 
impact on the genetic diversity of small and reduced populations in comparison to more extensive and robust ones (LEFÈvRE, 2001; HEDRICK, 2001). To avoid possible pollination from allochthonous sources, the in situ original plants (ortets) are vegetatively propagated. The collections can produce reproductive material for reintroduction projects or to supplement reduced populations. The loss of genetic diversity of the original populations cannot be undone and the inevitable relocation of individuals will influence the genetic variability of the future populations. Against this disadvantage stands the risk of extinction. Basic material of several species is collected in the Institute for Forestry and Game Management (Table 2).

\subsection{Dynamic conservation: autochthonous forest reproductive material.}

Conservation action is required even when the size of autochthonous populations is sufficient and natural regeneration is present. This is because of the large quantity of planting stock from unknown provenances that are planted by both private owners and public organisations, in (re)forestations and in landscaping schemes. The use of autochthonous planting stock is a dynamic ex situ conservation strategy. It creates sustainable future opportunities for the genetic resources. It is a means of ecological restoration as for most of the native species, autochthonous populations have become rare and endangered.

Since 1998 the Flemish Forest Administration has organised in situ seed collection in surveyed populations in Flanders. A few other non-profit organisations are also involved in collaboration with the Administration. No seeds or cuttings from rare species are collected, or only in small amounts for small-scale projects (Table 2). Shrub species such as Rubus spp. or Ribes spp. are not threatened and therefore are not included. Surveyed sites with neighbouring plantations are omitted because of the risk of cross-pollination from unknown provenances. Seeds are obtained from at least 30 seed-bearing plants per species within one region of provenance. As the surveyed sites are mostly fragmented, small, and are not managed towards seed production, different sites are visited for every species. This implies a timeconsuming and costly effort. The Flemish legislation allows the mixing of seed lots within one region of provenance. This practice guarantees a sufficient genetic variability in the planting stock. The planting stock for the state forests is grown in two governmental nurseries located in Koekelare and in Brasschaat. Seeds collected by other organisations are raised in private nurseries under a sales-contract.

Since 2004 seed collection has been possible on surveyed sites approved as seed sources or stands, primarily under the new category 'source identified'. Here, at least 30 individuals are present of the same species with a good score for autochthony in the inventory. Nonautochthonous neighbouring plantations are absent. Approval files for every seed source or stand are collated at the Institute for Forestry and Game Management. At the beginning of 2005 the first 26 seed sources and stands were approved (Table 1). Autochthonous stands showing traits of a silvicultural value are approved under the category 'selected'. This is the case for five stands of Alnus glutinosa and one of Quercus robur.

\subsection{Seed orchards}

In comparison to the labour-intensity and cost of in situ seed collection from wild populations, seed orchards hold many advantages. They produce large amounts of vital seeds and at the same time preserve the gene pool of the autochthonous populations from which the seedbearing plants originate. Current seed stands and orchards of the category 'selected' or higher in Flanders are small in area and in number and do not contain material from autochthonous quoted populations of native tree species, except for the autochthonous stands of A. glutinosa (5) and Quercus robur (1) (Table 1). Seed sources, stands or orchards for shrubs were absent until 2003. The establishment of autochthonous seed orchards is supported by the Flemish policy ('loss of biodiversity' of the Environmental policy plan of the Flemish Government) (ANONYMOUs, 2003d).

Basic material for the seed orchards has been collected at the Institute for Forestry and Game Management since 1999 (Table 1). The number of provenance regions for which seed orchards are established differs between the species, depending on their natural dispersal pattern. E.g. poorer soils of the Campine region of provenance support a distinct spectrum of species as compared to the richer soils of Brabant District East. For some rare and dispersed species such as Tilia cordata and Ulmus laevis few relict populations exist. As there is a demand for forest reproductive material of these species, orchards are created with basic material from the whole of Flanders (see 2.3). The most firmly authenticated autochthonous trees and shrubs are propagated, mainly vegetatively, from geographically scattered sites within the provenance region, to represent the genetic variation of the area. The use of vegetatively propagated plants for the seed orchards holds the advantage over the use of seedlings as no pollination from nonautochthonous sources can interfere. Especially for old coppice stools, but also for shaded and therefore nonflowering trees and shrubs, it can be of interest to have access to the exact genetic copies. In evolutionary terms, only one generation of genetic information exchange is missed thereby. Also, flowering may commence earlier in clonal seed orchards. The practical disadvantage is the difficult and cost-intensive process of vegetative propagation, particularly for recalcitrant genera such as Quercus. Experienced greenhouse technicians are indispensable. Labour- and cost-intensive in vitro techniques are not applied as yet. In later stages the clones can serve as parental material for breeding purposes. Every seed orchard contains a minimum of 50 genotypes per species and up to 3 ramets per genotype. Although little scientific proof is available (e.g. RoBERDS et al., 1997), 30 to 40 genetically unrelated genotypes is considered as a minimum for adequate population fitness.

\subsection{Concluding remarks and research needs}

Flanders represents a region where autochthonous genetic resources of woody plants are particularly 
threatened due to the consequences of a dense human population. A systematic inventory has been the starting point for several conservation actions. These include the creation of clonal banks for rare species and the production of autochthonous forest reproductive material.

For some species it can be questioned whether the natural genetic mechanisms will be sufficient to counteract the losses in genetic variability. E.g., only 21 different genotypes of Populus nigra were traced in the whole of Belgium (1.3 million ha, personal communication An Vanden Broeck). Even if the threat of extinction is not imminent, the gene pool may become too reduced to safeguard adaptive capacity. Therefore, conservation actions are crucial for the long-term survival of most native species. In addition, economic priorities may recommend a broad genetic diversity, as certain phenotypic traits may gain economic importance in the future that today are looked at with indifference.

The debate on whether or not 'local is the best' is ongoing and active. There is an urgent need to define scientifically based seed transfer zones. Information is necessary on aspects of adaptation and adaptability, to be obtained through provenance trials that include local provenances and through research on introgression between locally adapted and non-autochthonous genotypes (KLEINSCHMIT et al., 2004). It is clear that research employing routinely applied neutral molecular markers is helpful in informing genetic conservation efforts (e.g. PARKER et al., 1998; SUNNUCKS, 2000). However, these methods lack a direct correlation with adaptation and adaptability. Functional markers would be more useful but are at too early a stage of development (ANDERSEN and LÜBBERSTEDT, 2003). On the other hand, classical provenance trials and other reciprocal transplantation tests of parental genotypes may offer the necessary insights to assess the effects of seed transfer on population fitness and are necessary tools to delineate the regions of provenance. To this purpose two provenance trials were established for $Q$. petraea in 2003 that compare offspring of several autochthonous coppice stands with planting stock from approved seed stands in Belgium and in neighbouring regions.

The importance of in situ conservation measures is clearly indicated at a pan-European scale (EUFORGEN, 2005). In Flanders, actions are mainly focussed on ex situ conservation, for two reasons. Firstly, autochthonous populations are mostly very small and highly fragmented and plantations of non-autochthonous provenances are omni-present. Secondly, populations are often on private property. In many cases one population is the property of several land owners. The legal background is missing in Flanders to safeguard these valuable populations. This makes it difficult to convince all the owners to protect and maintain the autochthonous populations on their land. To date, in situ conservation has mainly been restricted to awareness-raising actions (Cox et al., 2005).

Finally, tree and shrub species have much longer generation times in comparison to agricultural crops. Therefore, the choice of provenance implies a higher risk as mistakes can become visible only after many years. In view of the predicted climate change, the safest option is to maintain the present genetic diversity of autochthonous trees and shrubs. They may have a better chance of surviving the possible coming changes.

\section{Acknowledgements}

We wish to thank in particular SCOTT WILSON for revision of the manuscript. In addition we thank STEFAAN Moreels and STEVen Haelterman for excellent work in the greenhouse and in the nursery. This work is supported by the Forest and Green Area division of the Flemish Community.

\section{References}

ANDERSEN, J. and T. LÜBBERSTEDT (2003): Functional markers in plants. Trends in Plant Science 8: 554-560.

ANONYMous (2000): Council Directive 1999/105/EC of 22 December 1999 on the marketing of forest reproductive material. Official Journal of the European Communities, 15 January L11: 17-40.

ANONYMOUS (2003a): 3 oktober 2003 - Besluit van de Vlaamse regering betreffende de procedure tot erkenning van bosbouwkundig uitgangsmateriaal en het in de handel brengen van bosbouwkundig teeltmateriaal. Belgian Law Gazette, 11 November: 54793-54824.

ANONYMOUs (2003b): 27 juni 2003 - Besluit van de Vlaamse regering betreffende de subsidiëring van beheerders van openbare en privé-bossen. Belgian Law Gazette, 10 September: 45431-45500.

ANONYMOUS (2003c): 28 maart 2003 - Besluit van de Vlaamse regering betreffende de subsidiëring van de bebossing van landbouwgronden ter uitvoering van de Verordening (EG) nr. 1257/1999 van de Raad van 17 mei 1999 inzake steun voor plattelandsontwikkeling uit het Europees Oriëntatie- en Garantiefonds voor de landbouw (EOGFL) en tot wijziging en instelling van een aantal verordeningen. Belgian Law Gazette, 19 May: 27184-27199.

ANONYMous (2003d): Environmental Policy Plan of the Flemish Government, www.milieubeleidsplan.be.

BD (2004): Bosdecreet 13 juni 1990 B.S.28.09.1990, www.gestelsewijk.be/bosdecreet/.

Behm, A., A. Beckers, H. Dorflinger, A. Franke, J. Kleinschmit, G. H. Melchior, H.-J. Muhs, H. P. Schmitt, B. R. Stephan, U. TABel, H. Weisgerber and H. WidMAIER (1997): Concept for the Conservation of Forest Genetic Resources in the Federal Republic of Germany. Sivae Genetica 46: 24-34.

CBD (1992): Convention on Biological Diversity, Rio de Janeiro, Argentina, www.biodiv.org/convention/.

COART, E. (2003): Molecular contributions to the conservation of forest genetic resources in Flanders: genetic diversity of Malus sylvestris, Quercus spp. and Carpinus betulus. PhD., Universiteit Gent, Gent.

Cox, K., K. VAnder MiJnsbrugge and J. VAN SLycken (2005): Impact of recent European and national policies: the promotion of regional basic material in Flanders (Northern Belgium), pp. 97-108 in Small-scale Forestry in a Changing Environment, Proceedings of the International Symposium IUFRO, Research group 3.08.00 Small-scale Forestry, May 30-June 4, Vilnius, Lithuania.

Danusevicius, D. and B. Persson (1998): Phenology of natural Swedish populations of Picea abies as compared with introduced seed sources. Forest Genetics 5: 211-220. 
De Keersmaeker, L., N. Rogiers, R. Lauriks and B. De Vos (2001): Ecosysteemvisie bos in Vlaanderen, Ruimtelijke uitwerking van de natuurlijke bostypes op basis van bodemgroeperingseenheden en historische boskaarten. VLINA C97/06, Ministry of the Flemish Community, Brussels.

Ennos, R. A., R. Worrell, P. Arkle and D. C. Malcolm (2000): Genetic Variation and Conservation of British Native Trees and Shrubs: Current Knowledge and Policy Implications. Technical Paper 31, Forestry Commission, Edinburgh.

EUFORGEN (2005): European Forest Genetic Resources Programme, www.ipgri.cgiar.org/networks/euforgen.

Forest and Green Areas Division (2001): Beheervisie openbare bossen. Ministry of the Flemish Community, Brussels.

Forest and Green Areas Division (2003): Actieplan Bosbouw. Ministry of the Flemish Community, Brussels.

Frankel, O. H., A. H. D. Brown and J. J. Burdon (1995): The conservation of plant biodiversity. Cambridge University Press, Cambridge.

Graudal, L., E. D. KJÆR and S. CANGER (1995): A systematic approach to the conservation of genetic resources of trees and shrubs in Denmark. Forest Ecology and Management 73: 117-134.

GREGORIUS, H. R. and J. KLEINSCHMIT (1999): The environmental dichotomy of adaptation and the role of genetic diversity. Silvae Genetica 48: 193-199.

HAmRICK, J. L., M. J. W. GodT and S. L. Sherman-Broyles (1992): Factors influencing levels of genetic diversity in woody plant species. New Forests 6: 95-124.

HeDRICK, P. W. (2001): Conservation genetics: where are we now? Trends in Ecology \& Evolution 16: 629-636.

Herbert, R., S. SAmuel and G. Patterson (1999): Using Local Stock for Planting Native Trees and Shrubs. Practice Note 8, Forestry Commission, Edinburgh.

Hufford, K. and S. MAZER (2003): Plant ecotypes: genetic differentiation in the age of ecological restoration. Trends in Ecology and Evolution 18: 147-155.

Joly, H. and N. Frascaria-Lacoste (2001): Introduction to population genetics, pp. 11-15 Forest Genetic Resources Management and Conservation. France as a case study, edited by E. TEISSIER DU Cros, Ministry of Agriculture and Fisheries, Bureau of Genetic Resources, Commission of Forest Genetic Resources, INRA DIC, Paris.

Jones, A. T., M. J. Hayes and N. Sackville Hamilton (2001): The effect of provenance on the performance of Crataegus monogyna in hedges. Journal of Applied Ecology 38: 952-962.

KITZMiLleR, J. H. (1990): Managing genetic diversity in a tree improvement program. Forest Ecology and Management 35: 131-149.

KLeinschmit, J. R. G., D. KownAtzKi and H. R. GREgoRIUS (2004): Adaptational characteristics of autochthonous populations - consequences for provenance delineation. Forest Ecology and Management 197: 213-224.

LEFÈVRE, F. (2001): Static conservation of collections, pp. 29-32 in Forest Genetic Resources Management and Conservation. France as a case study, edited by E. TEISsier DU CROs, Ministry of Agriculture and Fisheries, Bureau of Genetic Resources, Commission of Forest Genetic Resources, INRA DIC, Paris.

Maes, N., T. van VuURe and G. Prins (1991): Inheemse bomen en struiken in Nederland. Stichting Kritisch Bosbeheer, Utrecht.
MAES, N. (1993): Genetische kwaliteit inheemse bomen en struiken. Deelproject: Randvoorwaarden en knelpunten bij behoud en toepassing van inheems genenmateriaal. IBN-rapport 20, IKC-NBLF, IBN-DLO, Wageningen.

MAES, N. and C. RövEKAMP (1998): Oorspronkelijk inheemse bomen en struiken in Vlaanderen. Een onderzoek naar autochtone genenbronnen in de Ecologische Impulsgebieden. Ministry of the Flemish Community, Brussels.

MAES, N. and C. RövEKAMP (2000): Oorspronkelijk inheemse bomen en struiken in het Regionaal Landschap Vlaamse Ardennen. Een onderzoek naar autochtone genenbronnen. Ministry of the Flemish Community, Brussels.

Maes, N., C. Rövekamp, B. Opstaele and A. Zwaenepoel (2003): Oorspronkelijk inheemse bomen en struiken in de houtvesterijen Antwerpen en Turnhout. Ministry of the Flemish Community, Brussels.

MCPFE (2005): Ministerial Conferences on the Protection of Forests in Europe, www.minconf-forests.net.

Newton, A. C., T. R. Allnutt, A. C. Gillies, A. J. Lowe and R. A. EnNos (1999): Molecular phylogeography, intraspecific variation and the conservation of tree species. Tree 14: 140-145.

Opstaele, B. (2001): Autochtone bomen en struiken in de houtvesterijen Leuven en Hasselt. Ministry of the Flemish Community, Brussels.

Parker, P., A. Snow, M. Schug, G. Booton and P. Fuerst (1998): What molecules can tell us about populations: choosing and using a molecular marker. Ecology 79: 361-382.

PigotT, C. B. (1989): Factors controlling the distribution of Tilia cordata Mill at the northern limits of its geographical range. IV. Estimated ages of the trees. New phytology 112: 117-121.

PRAT, D. and J. BurczYK (1998): Genetic variation and mating system in a native provenance and the derived seed orchard of douglas-fir (Pseudotsuga menziesii (Mirb.) Franco). Forest Genetics 5: 201-209.

RoBERDS, J. H. and J. W. BISHIR (1997): Risk analyses in clonal forestry. Canadian Journal of Forestry Research 27: 425-432.

RöveKAMP, C. and N. MAes (1999): Oorspronkelijk inheemse bomen en struiken in Vlaanderen. Een onderzoek naar autochtone genenbronnen in de Regionale Landschappen West-Vlaamse Heuvels, Vlaamse Ardennen en de houtvesterijen Hechtel en Bree. Ministry of the Flemish Community, Brussels.

RöveKAMP, C., and N. MAES (2000): Oorspronkelijk inheemse bomen en struiken in het Regionaal Landschap West-Vlaamse Heuvels. Een onderzoek naar autochtone genenbronnen. Ministry of the Flemish Community, Brussels.

Rövekamp, C., N. Maes and A. Zwaenepoel (2000): Oorspronkelijk inheemse bomen en struiken en cultuurwilgen in de Vlaamse Vallei. Een onderzoek naar autochtone genenbronnen in Gent en omgeving. Ministry of the Flemish Community, Brussels.

Sackville Hamilton, N. R. (2001): Is local provenance important in habitat creation? A reply. Journal of Applied Ecology 38: 1374-1376.

SunNuCKS, P. (2000): Efficient genetic markers for population biology. Tree 15: 199-203.

Svolba, J. and J. KLEINSChMit (2000): Herkunftsunterschiede beim Eichensterben. Forst und Holz 55: 15-17.

TACK, G., P. van DEN BREMT and M. Hermy (1993): Bossen van Vlaanderen, een historische ecologie. Davidsfonds, Leuven, Belgium. 
TeIssien DU Cros, E. (2001): Forest Genetic Resources Management and Conservation. France as a case study, Ministry of Agriculture and Fisheries, Bureau of Genetic Resources, Commission of Forest Genetic Resources, INRA DIC, Paris.

VANDEn Broeck, A. (2004): Potential gene flow from cultivated poplar into native European Black poplar (Populus nigra L.) in Belgium. PhD. Universiteit Gent, Gent.

VAN DER BEN, D. (1997): Het Zoniënwoud. Een natuurmonument en zijn geschiedenis. Lannoo, Tielt, Belgium.

VAnder MiJnsbrugGe, K. (2003): Conservation of the heritage of autochthonous woody plants in Flanders (Belgium). Scripta Botanica Belgica 24, 105-115.

VAnder MijnsbrugGe, K., E. CoArt, H. Beeckman and J. VAN Slycken (2003a): Conservation measures for autochthonous oaks in Flanders. Forest Genetics 10 207-217.

Vander Mijnsbrugge, K., A. Van den Broeck, E. Coart, R. Devreese and M. Dumortier (2003b): Bomen en struiken, pp. 37-41 in Natuurrapport 2003 edited by M. Dumortier, L. De Bruyn, H. Peymen, A. Schneiders, T. Van Daele, G. Weyembergh, D. van Straaten and E. KuIJKEN, Instituut voor Natuurbehoud, Brussels.

Vander Mijnsbrugge, K., K. Cox and J. Van Slycken, 2004: Afbakening van Vlaamse herkomstgebieden, rapport Ibw.Bb.R.2004.001, Instituut voor Bosbouw en Wildbeheer, Geraardsbergen.

WAGNeR, I. (1999): Schutz und Nutzen von Wildobst. Probleme bei der direkten Nutzung von Wildobstrelikten. Forstarchiv 70: 23-27.

Wilson, S. M., D. C. Malcolm and D. A. Rook (1999): Locating natural populations of Scottish native trees. Scottish Forestry 53(4): 215-224.

Wilson, S. M. and C. J. A. SAmuel (2004): Genetic conservation of native trees, in Forest Research Annual Report and Accounts for 2002-2003, Forestry Commission, Edinburgh.

\title{
Classification of Genus Acanthopanax in Korea and Genetic Diversity Using Allozymes
}

\author{
By M. K. HuH ${ }^{1), *)}$ and H. W. HuH
}

(Received 20 ${ }^{\text {th }}$ April 2005)

\begin{abstract}
Genus Acanthopanax is a long-lived woody species that is primarily distributed throughout Asia. Many species of this genus are regarded as medically and ecologically important. We evaluated a representative sample of the nine taxa with allozymes to estimate genetic relationships within the genus. As some Korean populations were isolated and patchily distributed, they exhibited a low level of genetic diversity. The narrow geographic ranges, artificial distribution of habitats, and small population sizes are proposed as factors contributing to low genetic diversity. Acanthopanax seoulense was similar to $A$. sessiliflorus, while a cluster of the $A$. rufinerve population is distant from any other species. $A$. senticosus is closely related to $A$. seoulense and $A$. sessiliflorus, whereas other species (A. koreanum) are more distinct from the Korean populations. Korean species are clustered together and clearly differentiated from the Chinese and Russian Acanthopanax taxa, genus Acanthopanax
\end{abstract}

Key words: Allozyme; Genetic relationships; Genus Acanthopanax.

\section{Introduction}

The genus Acanthopanax or Eleutherococcus is a genus within the subfamily Araliaceae comprising of the

1) Department of Molecular Biology, Dongeui University 995 Eomgwangno, Busanjin-gu, Busan 614-714, Korea.

*) Corresponding author: MAN KyU HuH, Tel: +82-51-890-1529, Fax: +82-51-890-1521, E-mail address: $\underline{\text { mhuh@@eu.ac.kr }}$ diploid species $(2 \mathrm{n}=54)$ and distributed mainly in northeastern Asia. Acanthopanax can be classified as narrowly adapted species because they are usually found on the subsites of several mountains, at elevations of 600 to $1.000 \mathrm{~m}$. These long-lived perennials have purple, green, and white flowers and have a bisexual and mixed mating, reproductive system with selfing or out-crossing via insect-pollination (HUH et al., 2005). Although plants grow high in the mountains on fertile soil, they are also extensively cultivated as medicinal crops. Many species of this genus are economically important for their leaves, stems, and roots which historically were used in Korea for medicine, alcoholic liquor, and beverages.

A. senticosus native to northeastern China, Korea, and Japan and is presently prescribed for medicinal use in France, Germany, Korea, and China. A. koreanum, A. chiisanensis and $A$. seoulense are native to Korea and also a traditional medicine species.

A. senticosus is sold in the United States as "Siberian Ginseng”. It is known in China as ci wu Jia. It is also a more expensive medicine than other Acanthopanax species. Siberian Ginseng has been used for bronchitis, heart ailments, and rheumatism, and as a tonic to restore vigor, improve general health, restore memory, promote healthy appetite, and increase stamina (FosTER, 1996).

East Asian regions such as China, Korea, Japan and Russia are well known for various Acanthopanax species (LEE, 1997). The genus Acanthopanax is comprised of 